\title{
Macplocimine A, a new 18-membered macrolide isolated from the filamentous sulfur bacteria Thioploca sp.
}

\author{
Xiang $\mathrm{Li}^{1,2}$, Stephanie Vanner ${ }^{1,2}$, Wenliang Wang ${ }^{1,2}$, Yongchang $\mathrm{Li}^{1,2}$, Victor Ariel Gallardo ${ }^{3}$ \\ and Nathan A Magarvey ${ }^{1,2}$
}

Macplocimine A (1), a rare naturally occurring 18-membered macrolide, was isolated from the marine-derived filamentous sulfur bacteria Thioploca sp. The structure was determined by a combination of spectroscopic techniques, including HRESIMS, 1D and 2D NMR analyses. 1 features a thymine group, which is attached to an aromatic fused 18-membered macrolide ring structure derived from a polyketide synthase biosynthetic pathway.

The Journal of Antibiotics (2013) 66, 443-446; doi:10.1038/ja.2013.52; published online 19 June 2013

Keywords: macplocimine A; 18-membered macrolide; Thioploca sp.

\section{INTRODUCTION}

Natural products can exhibit potent pharmaceutical activity and as a result, are of significant interest for medicinal treatments. ${ }^{1}$ They are derived from diverse sources, such as plant, bacteria, fungi and marine invertebrates, and can be found in a broad range of environments. Layers of bacteria combined with sediment, or microbial mats, ${ }^{2}$ have proven to be a particularly important source of novel chemical compounds, including polyketides and nonribosomal peptides. These mats develop in various extreme environments, including polar regions, hot springs or hypersaline bodies of water. ${ }^{3}$ To date, mats composed of photosynthetic microbes, specifically cyanobacteria, have been the most thoroughly investigated and have been shown to produce a number of biologically active secondary metabolites. ${ }^{4}$ The non-photosynthetic bacteria of an individual mat can be composed of sulphur-metabolizing, ironoxidizing, hydrogen-oxidizing actinobacteria and methantrophic species. ${ }^{5-7}$ Of these, one of the most promising components is the sulphur-oxidizing bacteria that are abundant in highly specific marine environments. Thioploca and Beggiatoa are two genera of these bacteria that are well studied and understood for their sulphurmetabolizing abilities. ${ }^{8}$ They tend to develop in sulphur-rich marine environments such as estuaries, deep-sea hydrothermal vents, coldseeps and continental shelves. ${ }^{9}$ These areas include the Bay of Concepción in Chile, ${ }^{10}$ the Guaymas Basin, ${ }^{11}$ Tokyo Bay, ${ }^{12}$ the Monterey Canyon of California ${ }^{13}$ and cold seeps in the Atlantic Ocean. ${ }^{9,14}$ These genera are morphologically similar, with cells forming filaments that allow them to easily bundle to create mats. ${ }^{15}$
In addition to internally storing elemental sulphur, they have intracellular vacuoles containing high concentrations of nitrate. ${ }^{16}$ This is integral to the metabolism of sulphur under anaerobic conditions, as nitrate can be reduced to ammonia, acting as the electron acceptor during sulphide oxidation. ${ }^{17}$ Although these species' cycling of sulphur, carbon and nitrogen has been, and continues to be studied, their production of secondary metabolites and the associated enzymology remains unclear.

Recently, a filamentous species of Thioploca was obtained from the benthic microbial mat ecosystem on the continental shelf off the coast of Chile. We sought to determine the potential of these sulphuroxidizing bacteria to generate significant natural products. A small molecule, macplocimine A, was isolated and structurally defined.

\section{RESULTS AND DISCUSSION}

Phylogenetic analysis demonstrated that this Thioploca sp. can be grouped with several reported Thioploca and Beggiatoa species deposited in NCBI, and furthermore elucidated the evolutionary distinction of these sulphur-metabolizing bacteria from other bacterial classes (Figure 1, sequences are listed in Supplementary Information). A genome scan of Beggiatoa sp. using PKSJ (YP_006629905.1) sequence showed that this group of bacteria is a rich source of secondary metabolites. Detailed chemical investigation led us to the isolation and purification of a novel polyketide, namely Macplocimine A (1) (Figure 2). 1 was obtained as a pale yellow solid, with the molecular formula $\mathrm{C}_{27} \mathrm{H}_{36} \mathrm{O}_{9} \mathrm{~N}_{2}$, as deduced from HRESIMS $m / z$ : $531.2355[\mathrm{M}-\mathrm{H}]^{-}$(calcd 531.2343) (see Supplementary Figure 7),

${ }^{1}$ Department of Biochemistry and Biomedical Sciences, M.G. DeGroote Institute for Infectious Disease Research, McMaster University, Hamilton, Ontario, Canada; ${ }^{2}$ Department of Chemistry and Chemical Biology, M.G. DeGroote Institute for Infectious Disease Research, McMaster University, Hamilton, Ontario, Canada and ${ }^{3}$ Departamento de Oceanografia, Facultad de Ciencias Naturales y Oceanograficas, Investigador Asociado Centro de Biotecnologia, Universidad de Concepcion, Concepcion, Chile

Correspondence: Professor N Magarvey, Department of Biochemistry and Biomedical Sciences, M.G. DeGroote Institute for Infectious Disease Research, McMaster University, 1280 Main Street West, Hamilton, Ontario, Canada L8N $3 Z 5$.

E-mail: magarv@mcmaster.ca

Received 31 January 2013; revised 8 April 2013; accepted 12 April 2013; published online 19 June 2013 


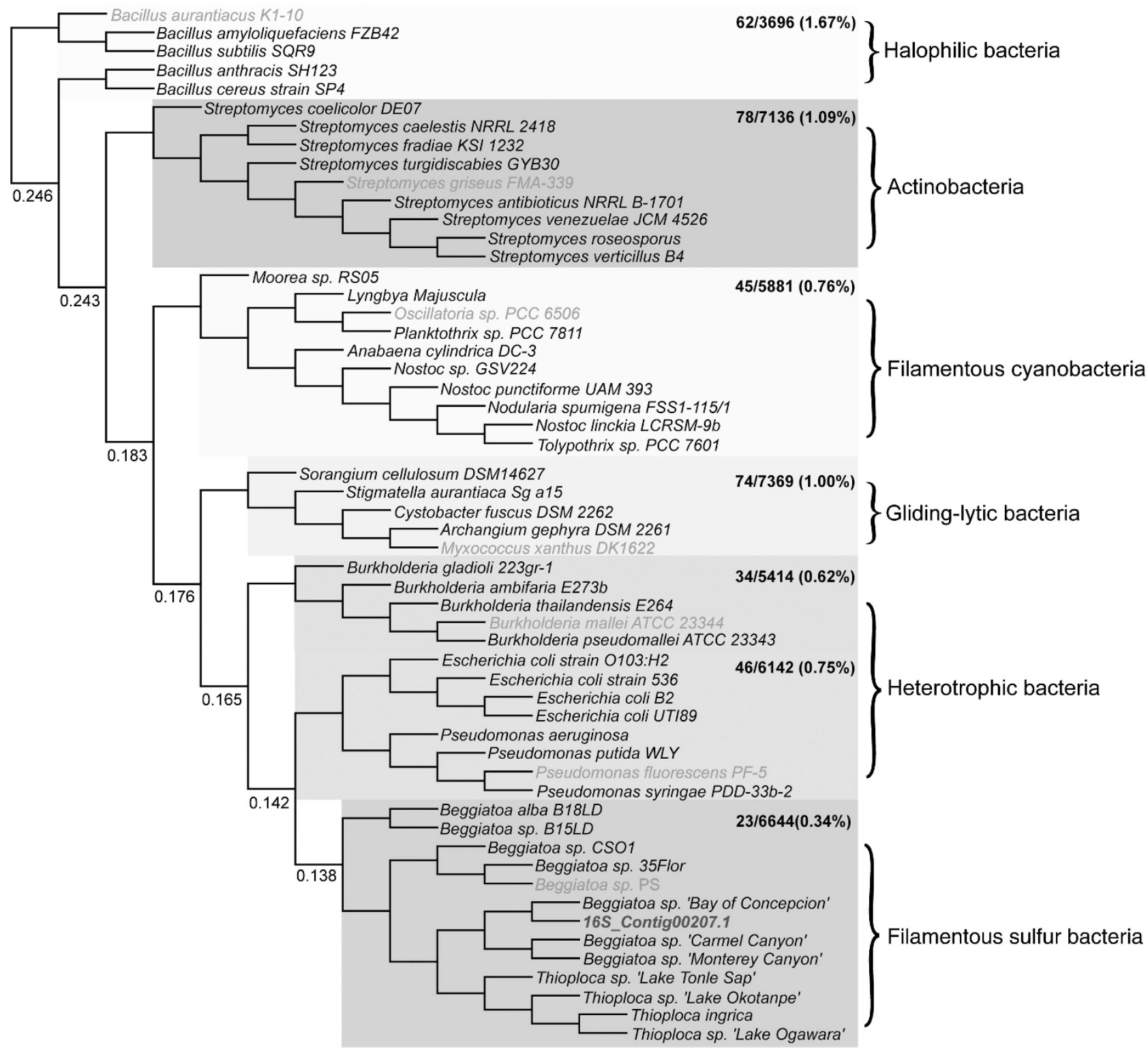

Figure 1 Phylogenetic analysis of $16 \mathrm{~S}$ sequence of Thioploca sp. Six groups were assigned based on the phylogenetic analysis: halophilic bacteria, actinobacteria, filamentous cyanobacteria, gliding-lytic bacteria, heterotrophic bacteria and proteobacteria. A full color version of this figure is available at The Journal of Antibiotics journal online.

requiring eleven sites of unsaturation. The UV-vis spectrum exhibited absorption maxima at 224, 264 and $302 \mathrm{~nm}(\mathrm{MeOH})$. Analysis of the ${ }^{1} \mathrm{H}$ NMR spectrum of $\mathbf{1}$ (see Supplementary Figure 1) in combination with the DEPT-Q (see Supplementary Figure 2) and HSQC (see Supplementary Figure 4) spectra indicated the presence of one heterocyclic proton $\left(\delta_{\mathrm{H}} 7.95\right)$, two aromatic protons $\left(\delta_{\mathrm{H}} 6.11\right.$ and 6.17), two olefinic protons $\left(\delta_{\mathrm{H}} 5.37\right.$ and 5.43), one $N$-methine $\left(\delta_{\mathrm{H}} 5.92\right)$, three oxygenated methines $\left(\delta_{\mathrm{H}} 4.39,3.80\right.$, and 3.46$)$, one methine $\left(\delta_{\mathrm{H}} 1.52\right)$, seven methylenes $\left(\delta_{\mathrm{H}} 2.73-0.94\right)$, as well as two methyl $\left(\delta_{\mathrm{H}} 2.39\right.$ and 0.80$)$ protons. The ${ }^{1} \mathrm{H}$ and ${ }^{13} \mathrm{C}$ NMR chemical shifts were all adequately assigned by detailed analysis of ${ }^{1} \mathrm{H}-{ }^{1} \mathrm{H}$ COSY (see Supplementary Figure 3), HSQC, and HMBC (see Supplementary Figure 5) spectroscopic data. The connectivity from C-2 to C-15 was confirmed by the continuous array of COSY couplings, thus the chain system was established (Figure 3 ), in which the double bond was assigned to $\mathrm{C}-6\left(\delta_{\mathrm{C}} 137.1\right)$ and $\mathrm{C}-7\left(\delta_{\mathrm{C}} 123.8\right)$ accordingly.
Down-field chemical shifts of $\mathrm{H}-4 \quad\left(\delta_{\mathrm{H}} \quad 4.39\right), \quad \mathrm{H}-8$ $\left(\delta_{\mathrm{H}} 3.80\right)$ and $\mathrm{H}-12\left(\delta_{\mathrm{H}} 3.46\right)$ indicated that C-4, C- 8 and $\mathrm{C}-12$ were oxygenated. A tetra-substituted aromatic ring was established by HMBCs between $\mathrm{H}-17\left(\delta_{\mathrm{H}} 6.17\right)$ and $\mathrm{C}-19\left(\delta_{\mathrm{C}} 100.5\right), \mathrm{C}-18$ $\left(\delta_{\mathrm{C}} 161.7\right)$ and $\mathrm{C}-21\left(\delta_{\mathrm{C}} 146.2\right)$, and between $\mathrm{H}-19$ and $\mathrm{C}-17\left(\delta_{\mathrm{C}}\right.$ 109.4), C-18, C-20 ( $\left.\delta_{\mathrm{C}} 161.4\right)$ and C-21 ( $\left.\delta_{\mathrm{C}} 146.2\right)$. The thymine structure was established by HMBCs between methyl $\mathrm{H}-27\left(\delta_{\mathrm{H}} 2.39\right)$ and C-24 $\left(\delta_{\mathrm{C}} 161.5\right), \mathrm{C}-25\left(\delta_{\mathrm{C}} 136.8\right)$ and $\mathrm{C}-26\left(\delta_{\mathrm{C}} 138.1\right)$, and $\mathrm{H}-26$ $\left(\delta_{\mathrm{H}} 7.95\right)$ and $\mathrm{C}-23\left(\delta_{\mathrm{C}} 156.3\right), \mathrm{C}-24$ and $\mathrm{C}-25$. The thymine group was linked to C-2 $\left(\delta_{\mathrm{C}} 66.2\right)$ based on HMBCs between H-26 and C-2 and $\mathrm{H}-2\left(\delta_{\mathrm{H}} 5.92\right)$ and $\mathrm{C}-23$ and C-26. The HMBCs between H-15 $\left(\delta_{\mathrm{H}} 2.53,2.73\right)$ and $\mathrm{C}-17$ and $\mathrm{C}-21$, and between $\mathrm{H}-17$ and $\mathrm{C}-15$ indicated that one side of the chain was attached to C-6; and the HMBCs between $\mathrm{H}-2$ and C-21 and C-1 $\left(\delta_{\mathrm{C}} 169.1\right)$ suggested that the other side of the chain was bridged by a lactone to $\mathrm{C}-21 .{ }^{1} \mathrm{H}$ and ${ }^{13} \mathrm{C}$ chemical shift indicated the presence of $Z$-geometry double bond 


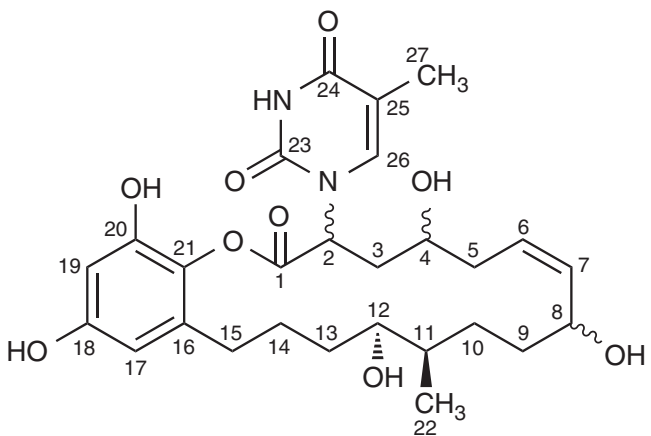

Figure 2 Structure of macplocimine A.

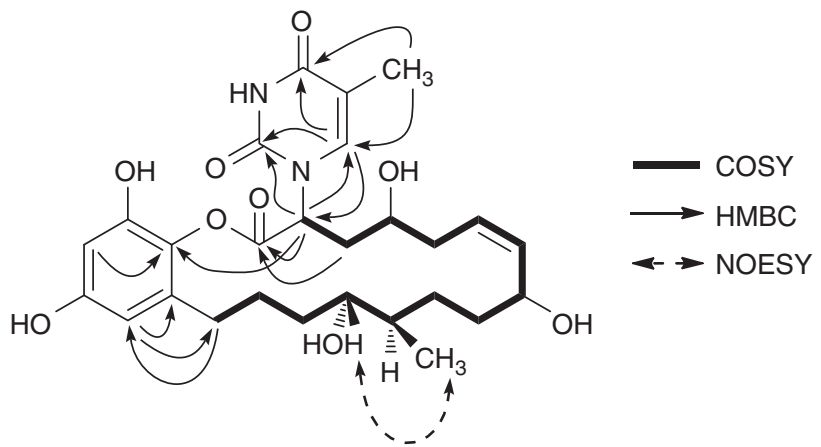

Figure 3 Key ${ }^{1} \mathrm{H}-^{13} \mathrm{C} \quad \mathrm{HMBC},{ }^{1} \mathrm{H}_{-}{ }^{1} \mathrm{H}$ COSY and NOESY (DMSO- $d_{6}$ ) correlations of macplocimine $\mathrm{A}$.

$\left(J_{6,7}=5.7 \mathrm{~Hz}\right)$ between C-6 $\left(\delta_{\mathrm{H}} 5.37 ; \delta_{\mathrm{C}} 137.1\right)$ and C-7 $\left(\delta_{\mathrm{H}} 5.43\right.$; $\delta_{\mathrm{C}}$ 123.8). Thus, the planar structure of 1 was determined as shown in Figure 2. The stereochemistry was not completely assigned due to the failure in crystallization and Mosher reaction attempts. The relative stereochemistry between $\mathrm{C}-11$ and $\mathrm{C}-12$ was, however, assigned as $11 \mathrm{~S}$ and $12 R$ based on NOESY (see Supplementary Figure 6) correlations between $\mathrm{H}-12\left(\delta_{\mathrm{H}} 3.46\right)$ and $\mathrm{H}-22\left(\delta_{\mathrm{H}} 0.80\right)$.

Macplocimine A was found to be structurally close to resorcylic acid lactones (RAL), a series of bioactive compounds showing interesting activities. ${ }^{18}$ For example, the 14-member ring radicicol is a potent and selective HSP90 inhibitor and hypothemycin, LL-Z1640-2 and LL-783, 277 were found to be potent kinase inhibitors. ${ }^{19,20}$ It will be interesting to test macplocimine A for either HSP90 or kinase inhibition activities. The recent characterization of the biosynthetic radicicol clustered from the endophytic fungus Chaetomium chiversii indicated that the type I polyketide synthases involved in RAL biosynthesis harbored large multidomain enzymes that iteratively catalyze the condensation of nine units of thioacetates or malonates. ${ }^{21}$ On the basis of the structural similarity, we propose that macplocimine A could also be derived from a polyketide synthase biosynthetic pathway.

\section{METHODS}

\section{General}

NMR spectra were recorded on a Bruker Avance $500 \mathrm{MHz}$ NMR spectrometer (Fremont, CA, USA) with a $5 \mathrm{~mm}$ inverse detection probe. ${ }^{1} \mathrm{H}$ and ${ }^{13} \mathrm{C}$ NMR chemical shifts were referenced to the solvent peak for DMSO- $d_{6}$ (Cambridge Isotope Laboratories, Andover, MA, USA) at $\delta_{\mathrm{H}} 2.49$ and $\delta_{\mathrm{C}} 39.5 \mathrm{ppm}$, respectively. The Silica gel $(200-300$ mesh) used for column chromatography, and silica gel GF254 $(10-40 \mu)$ used for TLC, were supplied by Sigma-Aldrich
Table $1{ }^{1} \mathrm{H}$ and ${ }^{13} \mathrm{C}$ NMR spectral data of macplocimine $\mathrm{A}(1)$ in DMSO- $d_{6}$

\begin{tabular}{|c|c|c|c|c|c|}
\hline $\mathrm{C} / \mathrm{H}$ & ${ }^{1} H N M R$ & ${ }^{13}$ C NMR & $\mathrm{C} / \mathrm{H}$ & ${ }^{1} H N M R$ & ${ }^{13}$ C NMR \\
\hline 1 & - & $169.1(\mathrm{C})$ & 13 & $1.24(\mathrm{~m})$ & $31.3\left(\mathrm{CH}_{2}\right)$ \\
\hline 2 & $5.92(\mathrm{dd}, 3.78,11.6)$ & $66.2(\mathrm{CH})$ & 14 & $1.54(\mathrm{~m})$ & $28.9\left(\mathrm{CH}_{2}\right)$ \\
\hline $3 a$ & $2.03(\mathrm{~m})$ & $35.2\left(\mathrm{CH}_{2}\right)$ & $15 a$ & $2.53(\mathrm{~m})$ & $35.1\left(\mathrm{CH}_{2}\right)$ \\
\hline $3 b$ & $2.42(\mathrm{~m})$ & - & $15 b$ & $2.73(\mathrm{~m})$ & - \\
\hline 4 & $4.39(\mathrm{~m})$ & $68.7(\mathrm{CH})$ & 16 & - & $106.5(\mathrm{C})$ \\
\hline $5 a$ & $2.18(\mathrm{~m})$ & $36.3\left(\mathrm{CH}_{2}\right)$ & 17 & $6.17(\mathrm{~s})$ & $109.4(\mathrm{CH})$ \\
\hline $5 b$ & $2.26(\mathrm{~m})$ & - & 18 & - & $161.7(\mathrm{C})$ \\
\hline 6 & $5.37(\mathrm{td}, 5.7,10.7)$ & $137.1(\mathrm{CH})$ & 19 & $6.11(\mathrm{~s})$ & $100.5(\mathrm{CH})$ \\
\hline 7 & $5.43(d, 5.7)$ & $123.8(\mathrm{CH})$ & 20 & - & $161.4(\mathrm{C})$ \\
\hline 8 & $3.80(\mathrm{~m})$ & $72.2(\mathrm{CH})$ & 21 & - & $146.2(\mathrm{C})$ \\
\hline $9 a$ & $1.30(\mathrm{~m})$ & $35.7\left(\mathrm{CH}_{2}\right)$ & 22 & $0.80(d, 6.62)$ & $15.0\left(\mathrm{CH}_{3}\right)$ \\
\hline $9 b$ & $1.54(\mathrm{~m})$ & - & 23 & - & $156.3(\mathrm{C})$ \\
\hline $10 a$ & $0.94(\mathrm{~m})$ & $27.9\left(\mathrm{CH}_{2}\right)$ & 24 & - & $161.5(\mathrm{C})$ \\
\hline $10 b$ & $1.25(\mathrm{~m})$ & - & 25 & - & $136.8(\mathrm{C})$ \\
\hline 11 & $1.52(\mathrm{~m})$ & $38.5(\mathrm{CH})$ & 26 & $7.95(\mathrm{~s})$ & $138.1(\mathrm{CH})$ \\
\hline 12 & $3.46(\mathrm{~m})$ & $72.7(\mathrm{CH})$ & 27 & $2.39(\mathrm{~s})$ & $13.6\left(\mathrm{CH}_{3}\right)$ \\
\hline
\end{tabular}

(St Louis, MO, USA). Spots were detected on TLC under UV light, or by heating after spraying with $5 \% \mathrm{H}_{2} \mathrm{SO}_{4}$ in $\mathrm{EtOH}(\mathrm{v} / \mathrm{v})$. HR- MS spectra were collected on a Thermo LTQ OrbiTrap XL mass spectrometer (ThermoFisher Scientific, Waltham, MA, USA) with an (ESI) and using collision-induced dissociation with helium for fragmentation. Preparative HPLC was conducted with Waters Alliance 2695 RP-HPLC separations module (Milford, MA, USA), equipped with a Waters 2998 photodiode array and a Luna $5 \mu \mathrm{m} \mathrm{C}_{18}$ column (250 mm $\times 10.0 \mathrm{~mm}$, Phenomenex). The water used for chromatography, UV, and MS was Millipore Milli-Q PF filtered and all of the solvents were HPLC grade.

\section{Sequence alignment and phylogenetic analysis}

Nucleotide sequences were aligned using the Geneious R6 program (Auckland, New Zealand), with default parameter settings (gap-opening penalty, 10; gap extension penalty, 0.05 ; gap separation penalty range, 8 ; identity for alignment delay, 40\%). The phylogenetic tree was constructed using the neighbor-joining algorithm with MEGA version 5 (Tempe, AZ, USA) with 1000 bootstrap trials performed.

\section{Extraction and isolation}

Thioploca sp. was obtained from the benthic microbial mat ecosystem on the continental shelf off the coast of Chile. The wet material was extracted with $95 \% \mathrm{EtOH}$ at room temperature for one week. The solvent was evaporated under reduced pressure to obtain an extract $(\sim 100 \mathrm{~g})$, which was suspended in $\mathrm{H}_{2} \mathrm{O}$ and then extracted with EtOAc. The EtOAc-soluble portion was subjected to vacuum liquid chromatography over silica gel eluted with gradient $\mathrm{CHCl}_{3}: \mathrm{MeOH}(9: 1,5: 1$ and $1: 1)$ to yield three fractions. Fraction 2 was separated on a Sephadex LH-20 column (Björkgatan, Uppsala, Sweden) and the subfraction 2-2 was subject to silica gel combiflash column, which was eluted with gradient hexane and EtOAc to give five fractions. Macplocimine A $(1,1.5 \mathrm{mg})$ was purified from fraction 2-2-1 using preparative HPLC with a linear gradient of methanol (from $50 \%$ to $90 \%$ ) for $35 \mathrm{~min}$ at a flow rate of $3 \mathrm{mlmin}^{-1}$.

Macplocimine A (1): pale yellow solid; UV (MeOH) $\lambda_{\max } 224,264,302 \mathrm{~nm}$; ${ }^{1} \mathrm{H}$ NMR and ${ }^{13} \mathrm{C}$ NMR data (DMSO- $d_{6}, 500 \mathrm{MHz}$ ), see Table 1; HRESIMS $m / z 531.2355[\mathrm{M}-\mathrm{H}]^{-}$(calcd for $\left.\mathrm{C}_{27} \mathrm{H}_{35} \mathrm{O}_{9} \mathrm{~N}_{2}, 531.2343\right)$.

\section{ACKNOWLEDGEMENTS}

This work was supported by the NSERC (2009C00053, to NAM) and by FONDECYT (Chile), Project \#1110786. 
1 Newman, D. J. \& Cragg, G. M. Natural products as sources of new drugs over the last 25 years. J. Nat. Prod. 34, 461-477 (2007).

2 Thornburg, C. C., Zabriskie, T. M. \& McPhail, K. L. Deep-sea hydrothermal vents: potential hot spots for natural products discovery? J. Nat. Prod. 73, 489-499 (2010).

3 Kubo, K., Knittel, K., Amann, R., Fukui, M. \& Matsuura, K. Sulfur-metabolizing bacterial populations in microbial mats of the Nakabusa hot spring, Japan. Systematic and Applied Microbiology. 34, 293-302 (2011)

4 Liu, L. \& Rein, K. S. New peptides isolated from the Lyngbya species: a review. Mar. Drugs. 8, 1817-1837 (2010).

5 Crepeau, V. et al. Diversity and function in microbial mats from the Lucky Strike hydrothermal vent field. FEMS Microbiol. Ecol. 76, 525-540 (2011).

6 Toner, B. M. et al. Mineralogy of iron microbial mats from lohi seamount. Front. Microbiol. 3, 1-18 (2012).

7 Pumphrey, G. M., Ranchou-Peyruse, A. \& Spain, J. C. Cultivation-independent detection of autotrophic hydrogen-oxidizing bacteria by DNA stable-isotope probing. Appl. Environ. Microbiol. 77, 4931-4938 (2011).

8 Zemsiakaia, T. I. et al. Ecophysiological features of mat-forming bacteria Thioploca in bottom sediments of Frolikha Bay, northern Baikal. Mikrobiologiia 70, 391-397 (2001).

9 Zhang, C. L. et al. Lipid biomarkers and carbon isotope signatures of a microbial (Beggiatoa) mat associated wtih gas hydrates in the Gulf of Mexico. Appl. Environ. Microbiol. 71, 2106-2112 (2005).

10 Gallardo, V. A. Large benthic microbial communities in sulphide biota under Peru-Chile Subsurface Countercurrent. Nature 268, 331-332 (1997).
11 Nelson, C. D., Wirsen, C. O. \& Jannasch, H. W. Characterization of large, autotrophic Beggiatoa spp. abundant at hydrothermal vents of the Guaymas Basin. Appl. Environ. Microbiol. 55, 2909-2917.

12 Kojima, H. \& Fukui, M. Phylogenetic analysis of Beggiatoa spp. from organic rich sediment of Tokyo Bay, Japan. Water Res. 37, 3216-3223 (2003).

13 Ahmad, A., Barry, J. P. \& Nelson, D. C. Phylogenetic affinity of a wide, vacuolate, nitrate-accumulating Beggiatoa sp. from Monterey Canyon, California, with Thioploca spp. Appl. Environ. Microbiol. 65, 270-277 (1999).

14 Otte, S. et al. Nitrogen, carbon, and sulfur metabolism in natural Thioploca samples. Appl. Environ. Microbiol. 65, 3148-3157 (1999).

15 Teske, A., Ramsing, N. B., Küver, J. \& Fossing, H. Phylogeny of Thioploca and related filamentous sulfide-oxidizing bacteria. System. Appl. Microbiol. 9, 517-526 (1995).

16 Fossing, H. et al. Concentration and transport of nitrate by the mat-forming sulphur bacterium Thioploca. Nature 374, 713-715 (1995).

17 Mußmann, M. et al. Phylogeny and distribution of nitrate-storing Beggiatoa spp. in coastal marine sediments. Environ. Microbiol. 5, 523-533 (2003).

18 Winssinger, N. \& Barluenga, S. Chemistry and biology of resorcylic acid lactones. Chem. Commun. 7, 22-36 (2007).

19 Wee, J. L., Sundermann, K., Licari, P. \& Galazzo, J. Cytotoxic hypothemycin analogues from Hypomyces subiculosus. J. Nat. Prod. 69, 1456-1459 (2006).

20 Dakas, P. Y., Jogireddy, R., Valot, G., Barluenga, S. \& Winssinger, N. Divergent syntheses of resorcylic acid lactones: L-783277, LL-Z1640-2, and hypothemycin. Chemistry 15, 11490-11497 (2009).

21 Wang, S et al. Functional characterization of the biosynthesis of radicicol, an $\mathrm{Hsp} 90$ inhibitor resorcylic acid lactone from. Chaetomium chiversii. 15, 1328-1338 (2008).

Supplementary Information accompanies the paper on The Journal of Antibiotics website (http://www.nature.com/ja) 